\title{
Immunochemical Studies of the Effect of Ionic Strength on Thermal Denaturation of Soybean 11S Globulin
}

\author{
Setsuko IwabuCHI and Kazuo SHIBASAKI \\ Department of Food Chemistry, Faculty of Agriculture, \\ Tohoku University, Sendai 980, Japan
}

Received August 13, 1980

\begin{abstract}
Using immunochemical technique thermal denaturation of soybean 1IS globulin, dissolved in different ionic strength solutions $(\mu=0 \sim 4.0)$ and heated at $100^{\circ} \mathrm{C}$ for $5 \mathrm{~min}$, has been quantitatively studied. The curves of the percentage of antigenicity remaining were obtained as a function of salt concentration. The $11 \mathrm{~S}$ globulin became strongly resistant to thermal denaturation with increasing both $\mathrm{KCl}$ and potassium phosphate. The stabilizing effect (in terms of percent antigenicity) was separated into three regions. At ionic strength below 0.7, potassium phosphate had no stabilizing effect while $\mathrm{KCl}$ had a slightly effect. The rise in stabilizing effect up to about $50 \%$, near $1.0 \sim 1.5 \mu$, represented a second transition to a different denatured state which retains undissociated molecule. At rises up to $75 \sim 95 \%$, near $2.5 \sim 3.5 \mu$, a different conformational state resulted in which thermally denatured $11 \mathrm{~S}$ globulin maintained almost intact native conformation after heating. The selection of an adequate ionic strength of protein solution has enabled preparation of thermally denatured $11 \mathrm{~S}$ globulins which have desired-residual amounts of structured regions.
\end{abstract}

Most studies on protein denaturation have been made with the structurally well defined proteins and have been reviewed by Tanford. ${ }^{1)}$ With soybean proteins, many reports have been published on the thermally induced denaturations which soy proteins undergo at various concentrations of salt. ${ }^{2 \sim 4)}$ Catsimpoolas et al. ${ }^{4)}$ found that aggregation of thermally denatured $11 \mathrm{~S}$ globulin was strongly dependent on the ionic strength, especially supressed by high salt concentrations $(0.1 \sim 2.0 \mathrm{M})$. Hermansson, ${ }^{5)}$ from her calorimetric studies, found that increasing of $\mathrm{NaCl}$ concentration zero to $1.0 \mathrm{M}$ increased the denaturation temperature by $20^{\circ} \mathrm{C}$. However, it has been apparent that salt has a stabilizing effect on the quaternary structure of $11 \mathrm{~S}$ globulin against dissociation, whereas there is little knowledge about quantitative aspects of the extent of its stabilizing effect.

In general, thermally denatured protein is not so extensively unfolded as the same protein denatured by strong denaturants and retains the regions of ordered structure ${ }^{1,6)}$ and salt stabilizes the native conformation against thermal denaturation. ${ }^{7,8)}$ By the use of an immunological technique with soy proteins, Catsimpoolas et al. demonstrated that $11 \mathrm{~S}$ globulin gives the immunoprecipitin band even by heating up to $90^{\circ} \mathrm{C}^{9}$ and supposed that loss of antigenicity in thermally denatured $11 \mathrm{~S}$ globulin is associated with conformational changes involving destruction of the quaternary structure. ${ }^{10)}$ An immunological technique provides a sensitive tool for the detection of structural changes produced in the antigen by the application of various treatments. ${ }^{1 \text { ) }}$ Recently, immunochemical methods have been used to investigate the refolding of denatured protein to its antigenic structure. ${ }^{12)}$ This experimental approach can be a very useful one since it can be used to detect immunologically unaltered $1 \mathrm{~S}$ globulin after heat treatment.

Although extensive studies have been made on soy proteins, more investigations are needed on the nature of the stabilizing effect of salt and the measurement of the extent of thermal denaturation. Therefore, we have made a detailed investigation of the effect of 
salts, such as $\mathrm{KCl}$ and potassium phosphate, on the thermal denaturation of $11 \mathrm{~S}$ globulin by means of immunochemical methods.

\section{MATERIALS AND METHODS}

Protein samples. Soybeans (var. Raiden) were defatted with $n$-hexane at room temperature. According to the procedure of Thanh and Shibasaki, ${ }^{13)}$ simultanious fractionated $11 \mathrm{~S}$ served as the source for crude $11 \mathrm{~S}$ protein. The purified $11 \mathrm{~S}$ globulin was prepared by ammonium sulfate fractionation followed by affinity chromatography with ConA-Sepharose 4B column and gel filtration with Sepharose $6 \mathrm{~B}$ column by the method of Kitamura et al. ${ }^{141}$ ConA-Sepharose $4 \mathrm{~B}$ and Sepharose 6B were obtained from Pharmacia. To prepare anti-11S serum, an aliquot of this protein fraction was dialyzed against the standard buffer $^{15)}(\mu=0.5, \mathrm{pH}$ 7.6) without 2-mercaptoethanol. Others were dialyzed against distilled water for complete desalting, adjusted to $\mathrm{pH} 7.0 \sim 7.2$ with $0.1 \mathrm{M} \mathrm{NaOH}$, and then lyophilized.

Buffers. Salts and other reagents were all analytical reagent grade or equivalent purchased from Nakarai Chemicals Ltd., and they were generally used without further purification. All aqueous solutions were prepared in glass distilled water containing $0.05 \% \mathrm{NaN}_{3}$. Standard buffer ( $\mathrm{pH} 7.6,0.5 \mu$ ) designated by Wolf and $\mathrm{Briggs}^{15}$ ) was composed of $0.0325 \mathrm{M} \mathrm{K}_{2} \mathrm{HPO}_{4}-0.0026 \mathrm{M} \mathrm{KH}_{2} \mathrm{PO}_{4}$ (phosphate buffer) at 0.1 ionic strength, $\mathrm{NaCl}$ at 0.4 ionic strength and $0.01 \mathrm{~m} 2$-mercaptoethanol. Buffers so far used for heat denaturation of soy proteins $\mathrm{s}^{2,3)}$ have been composed of phosphate buffer $(\mathrm{pH} 7.6)$ in the absence of $\mathrm{NaCl}$ at low ionic strengths $(\mu \leqq 0.1)$, and of phosphate buffer in the presence of various $\mathrm{NaCl}$ concentrations ${ }^{4)}$ $(\sim 2.0 \mathrm{M})$ at high ionic strengths. Solutions used throughout this work were prepared by separating this standard buffer compositions into $\mathrm{K}_{2} \mathrm{HPO}_{4}-\mathrm{KH}_{2} \mathrm{PO}_{4}$ buffer and $\mathrm{KCl}$ solvent, which possesses no buffer capacity, instead of NaCl.* The molar composition of the phosphate buffer (pH 7.6, $0.1 \mu$ ) was used as follows: $0.0062 \mathrm{M} \mathrm{KH}_{2} \mathrm{PO}_{4}$ and $0.0316 \mathrm{M} \mathrm{K}_{2} \mathrm{HPO}_{4}$ according to Wolf and Tamura. ${ }^{3}$ In order to prepare the desired ionic strengths more than 0.1 , the molar compositions were used to be integral multiples of the molar composition of $0.1 \mu$ phosphate buffer. The $\mathrm{pHs}$ of these buffers at the region of high ionic strength show up to 8.1. The $\mathrm{KCl}$ solutions of $11 \mathrm{~S}$ globulin show about $\mathrm{pH} 6.8$ and are used without further $\mathrm{pH}$ adjusting. The concentrations of salts are described in the results.

* The experiments with freeze denaturation of soybean protein are presently carried out in our laboratory under conditions where proteins are dissolved in $\mathrm{KCl}$ solvent instead of $\mathrm{NaCl}$, because $\mathrm{KCl}$ is more adequate from the standpoint of the cryohydric point of salts.
Denaturation of $11 \mathrm{~S}$ globulin with heat treatment. The four $\mathrm{ml}$ of $11 \mathrm{~S}$ dispersions $(0.5 \%)$ in various ionic strength solutions were centrifuged at $21,600 \mathrm{~g}$ for $20 \mathrm{~min}$ using a Hitachi 20 PR centrifuge. An $E_{280 \mathrm{~nm}}^{1 \%}$ of $8.04^{16)}$ was used to obtain the concentration of $11 \mathrm{~S}$ globulin in the resulting supernatant. The supernatant was devided into two portions; an aliquot of $11 \mathrm{~S}$ solution was provided to unheated protein solution for calculating the original protein concentration and residual aliquots $(3 \mathrm{ml})$ were put into the test tube $(16 \times 125 \mathrm{~mm}$, screw capped). The samples were then heated at $100^{\circ} \mathrm{C}$ in a boiling water bath for $5 \mathrm{~min}$ and quickly cooled in running water. The heating time, $5 \mathrm{~min}$, is significant in Tofu making on the textural properties. Turbidity of protein solutions $(0.5 \%)$ after heating was read at $420 \mathrm{~nm}$.

Immunochemical methods. Antisera to the native $11 \mathrm{~S}$ globulin were prepared according to the procedure of Koshiyama and Fukushima. ${ }^{17)}$ Only $10 \mathrm{mg}$ of $11 \mathrm{~S}$ globulin with foot pad injections was required for immunization of one rabbit compared with $200 \mathrm{mg}$ of protein by the method of Catsimpoolas and Meyer. ${ }^{18)}$ The antisera were stored at $-20^{\circ} \mathrm{C}$ after addition of $0.1 \% \mathrm{NaN}_{3}$. Under these conditions, antisera are stable for at least 1 year. The antisera produced had a high titer enough to apply the subsequent experiments, and showed only one precipitin line with 1IS antigen and the lack of cross reaction with $7 \mathrm{~S}$ antigen (Fig. 1B). Double gel immunodiffusion was carried out as follows: the gel medium consisted of $1 \%$ agar (Difco Co., Ltd.) in the standard buffer (pH 7.6, $0.5 \mu$ ) containing $0.05 \% \mathrm{NaN}_{3}$. An radial immunodiffusion was done for the measurement of the amount of antigenic 11S retained in heat-denatured 11S globulin according to the procedure of Mancini $e t a l .{ }^{193}$ The gel medium consisted of $1.2 \%$ agarose (Nakarai Chemicals) in pH 8.6 barbital-sodium barbital 0.0025 ionic strength. Thoroughly cleaned $10 \times 7.5 \mathrm{~cm}$ glass slide was placed on a level surface and $10 \mathrm{ml}$ of agarose containing $0.1 \sim 0.2 \mathrm{ml}$ antiserum was applied to each slide. A series of wells ( $3 \mathrm{~mm}$ diameter) was formed in each slide and exactly $4 \mu \mathrm{l}$ of antigen solution was applied to each well using a Hamilton microsyringe. Fifty four samples could be run on a single slide. Solutions $(0.01 \sim 0.1 \%)$ of a standard $11 \mathrm{~S}$ antigen were used for calibration. On the every slides, calibrations, unheated 11S solutions, and heat-treated $11 \mathrm{~S}$ solutions were applied at the same time to diminish an experimental error. The diameter of the halo was measured to the nearest $0.1 \mathrm{~mm}$ after $48 \sim 72 \mathrm{hr}$ of diffusion in a humid chamber at room temperature. The slides were immersed in saline $(0.15 \mathrm{M} \mathrm{NaCl})$ to wash a large proportion of unreacted antiserum from the gel. The slides were then stained with Coomassie Blue G-250 in $3.5 \% \mathrm{HClO}_{4}{ }^{20}$ and destained by diffusion in $\mathrm{MeOH}-$ $\mathrm{CH}_{3} \mathrm{COOH}-\mathrm{H}_{2} \mathrm{O}(20: 7: 73 \mathrm{v} / \mathrm{v})$. Results were calculated from a standard curve obtained by plotting the square of the diameter of the halo. Estimation of the amount of immunologically unaltered $11 \mathrm{~S}$ globulin remaining in each 
sample was made on the basis of the ratio of $A i / A O$, where $A i$ is the amount of remaining antigenic $11 \mathrm{~S}$ globulin after heating and $A o$ is the original amount of this antigen in untreated sample.

Disc electrophoresis. The Ornstein-Davis disc electrophoresis with $7.5 \%$ separating gel and $3.5 \%$ spacer gel was carried out using $5 \times 80 \mathrm{~mm}$ glass tubes according to Thanh and Shibasaki. ${ }^{13)}$ Each $25 \mu \mathrm{l}$ of heat-treated $11 \mathrm{~S}$ solutions $(0.5 \%)$ was placed on the top of the gel. Electrophoresis was conducted for $2 \mathrm{hr}$ with a constant voltage of $100 \mathrm{~V}$. Staining and destaining of polyacrylamide gels were carried out as described as above. Densitometric scanning was obtained with a Shimadzu dual wavelength TLC scanner CS 900.

\section{RESULTS}

\section{Qualitative aspects}

Radial immunodiffusion of $11 \mathrm{~S}$ globulin showed a linear relationship between the square of the ring diameter and the amount of $11 \mathrm{~S}$ globulin between $0.01 \%$ and $0.1 \%$ solutions (Fig. 1). Radial immunodiffusion could be provided as an accurate measurement of the amount of $11 \mathrm{~S}$ antigen in a heat-treated soy protein. The effects of thermal denaturation on the antigenic properties of $11 \mathrm{~S}$ globulin with anti-11S are shown in Fig. 2. Before heating, no major change was observed in the halo of the precipitation by the variation in the salt type and concentration. Qualitative analysis by double diffusion in Fig. 2 showed that the precipitin line changes into a clear line with an increase in the ionic strength. The radial immunodiffusion patterns represented well the structural changes produced in the $11 \mathrm{~S}$ antigen during heat treatment in a wide range of ionic strength $(0 \sim 4.0 \mu)$.

The 11S globulin denatured by heating in $\mathrm{K}_{2} \mathrm{HPO}_{4}-\mathrm{KH}_{2} \mathrm{PO}_{4}$ buffer at ionic strength below about 0.7 did not form even a little halo of precipitation with anti-11S. At ionic strength above 0.8 , a clear halo appeared around the well and then the ring gradually increased with an increase in concentration of salt. However, the intensity of the stained halo is almost identical with the precipitation of the native $11 \mathrm{~S}$ antigen. In spite of the sufficient ionic strengths up to 0.7 , complete disap-

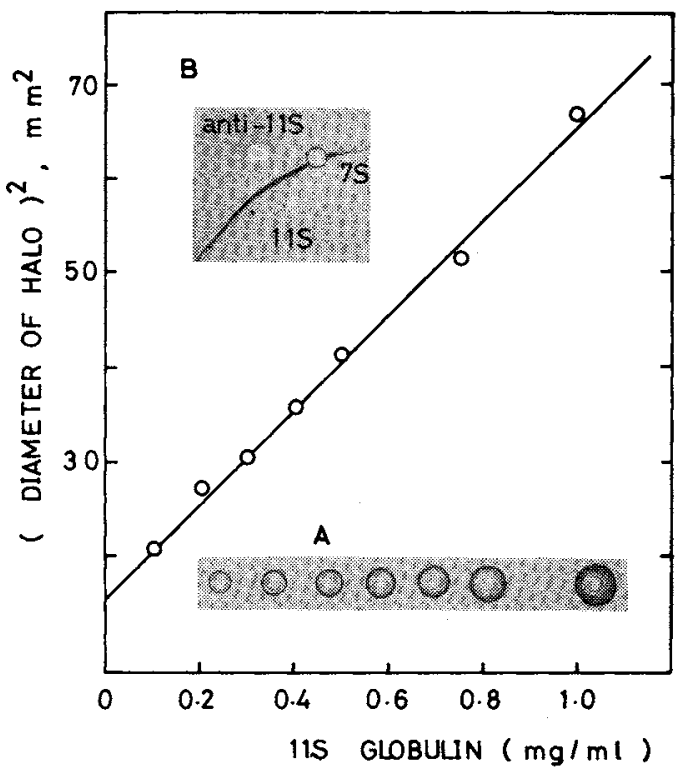

FIG. 1. Standard Curve for Radial Immunodiffusion. Four $\mu$ samples of $0.01 \sim 0.1 \% 11 \mathrm{~S}$ globulin diffused into $1 \%$ agarose gel in barbital buffer ( $\mathrm{pH} 8.6,0.025 \mu$ ) containing approximately $1 \%$ anti-11S serum. Inserts show stained pattern of radial immunodiffusion assay (A) and specificity of anti-11S serum checked by double diffusion (B).
1)
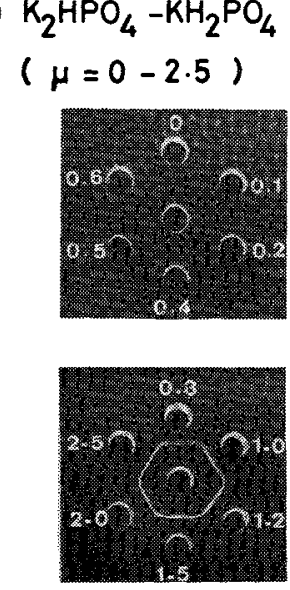

2) $\mathrm{KCl}$

$(\mu=0-3.0)$
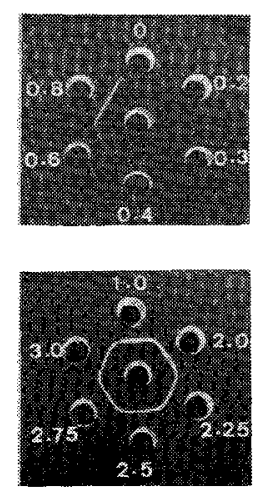

FIG. 2. Double Gel Immunodiffusion in Agar (Standard Buffer, pH 7.6, $0.5 \mu$ ) of $11 \mathrm{~S}$ Globulin Heattreated $\left(100^{\circ} \mathrm{C}, 5 \mathrm{~min}\right)$ with Various Ionic Strengths.

(1) $\mathrm{K}_{2} \mathrm{HPO}_{4}-\mathrm{KH}_{2} \mathrm{PO}_{4}$ buffer $(\mu=0 \sim 2.5)$ and (2) $\mathrm{KCl}$ solvent $(\mu=0 \sim 3.0)$. Center wells contained anti-11S.

pearance of antigenic 11S globulin occurred in $\mathrm{K}_{2} \mathrm{HPO}_{4}-\mathrm{KH}_{2} \mathrm{PO}_{4}$ buffer without any resist- 


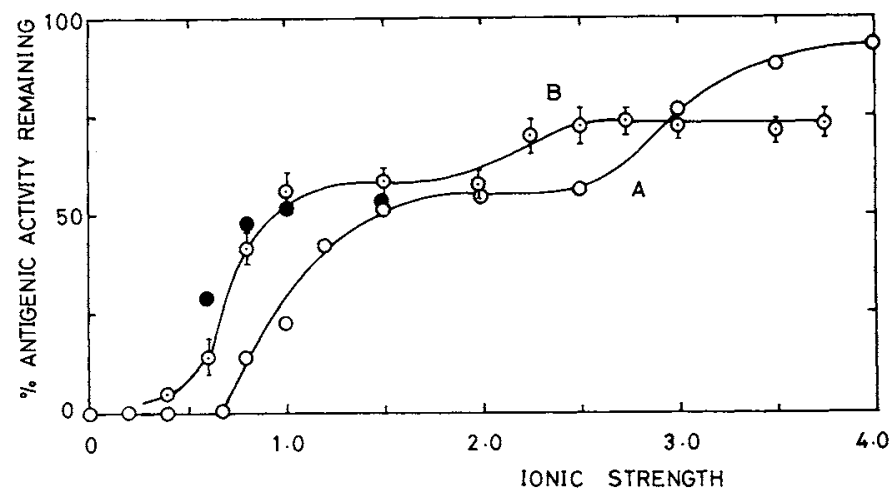

FIG. 3. Effect of Ionic Strength on Thermal Denaturation of $11 \mathrm{~S}$ Globulins Heated at $100^{\circ} \mathrm{C}$ for $5 \mathrm{~min}$.

Percent antigenic activities; remaining in $11 \mathrm{~S}$ globulin dissolved in $\mathrm{K}_{2} \mathrm{HPO}_{4}-\mathrm{KH}_{2} \mathrm{PO}_{4}$ buffer (A) $\mathrm{O}-\mathrm{O}, \mathrm{KCl}$ solvent $(\mathrm{B}) \odot-\odot$, and in $\mathrm{NaCl}$ solvent $(\odot)$. Analysis was quantitatively accurate within the $\pm 10 \%$ level in each of the 3 lots of solutions.

ance to heating $\left(100^{\circ} \mathrm{C}, 5 \mathrm{~min}\right)$. Therefore the effect of the ionic strength on the protection to thermal denaturation appeared at high ionic strength above 0.8 in phosphate buffer. In the case of $\mathrm{KCl}$ solvent, the antigenic properties differed from phosphate buffer in that a small halo of precipitation remains in the thermally denatured $11 \mathrm{~S}$ globulin even at the region of low ionic strength $(0.4 \sim 0.5 \mu)$. The size of the halo of $11 \mathrm{~S}$ globulin which remained in $\mathrm{KCl}$ solvent increased with an increase in concentration of $\mathrm{KCl}$. As compared with $\mathrm{K}_{2} \mathrm{HPO}_{4}-\mathrm{KH}_{2} \mathrm{PO}_{4}$ buffer, the resistance to thermal denaturation was already recognized at $0.4 \mu$ in $\mathrm{KCl}$ solvent.

\section{Quantitative aspects}

Figure 3 shows the percent antigenicity remaining in the thermally denatured $11 \mathrm{~S}$ globulin as a function of salt concentration. It is remarkable that thermal denaturation of $11 \mathrm{~S}$ globulin occurred in two distinct steps as indicated by immunologic properties by up to $100^{\circ} \mathrm{C}$. In curve A (Fig. 3) one occurs between 0.7 and $1.5 \mu$, and the second between 2.5 and $3.5 \mu$. With phosphate buffer, there is a plateau region between 1.5 and $2.5 \mu$ and the curve starts to elevate again up to $95 \%$ antigenic activity remaining. In curve $B$ (Fig. 3) one occurs between zero and $1.0 \mu$, and the second between 2.0 and $2.5 \mu$. With $\mathrm{KCl}$ solvent, there

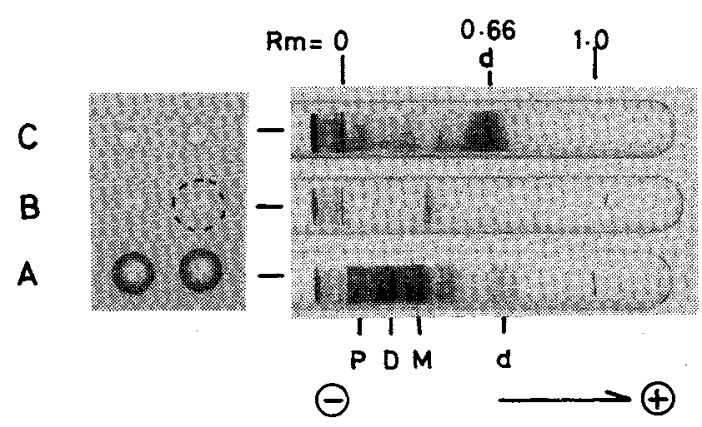

FIG. 4. Changes in Antigenic Properties of Modified 11S Globulins against Anti-11S and Disc Electrophoresis Patterns.

(A) treated with $N$-ethylmaleimide and freeze-dried, (B) intermediary subunit, a pair of $\mathrm{A}_{4}$ and $\mathrm{B}_{4}$ subunits, (C) reduced and $S$-carboxyamidemethylated $11 \mathrm{~S}$. Protein concentration was $0.1 \% . \mathrm{P} ; 11 \mathrm{~S}$ polymer, $\mathrm{D} ; 11 \mathrm{~S}$ dimer, $\mathrm{M}$; 11S monomer, $\mathrm{d}$; dissociates into subunits.

is also a flatten region between 1.0 and $2.0 \mu$ and a slight increase in antigenic activity. However, the maximum amount of antigenic activity remaining at the region of high $\mathrm{KCl}$ concentration shows only $75 \%$ which is less than that of phosphate buffer described above. Antigenic activity remaining of $\mathrm{KCl}$ solvent was distinctly different from that of phosphate buffer at regions of both below $1.5 \mu$ and above $3.0 \mu$. The curve A was shifted toward the region of higher ionic strength by 0.5 as compared with curve $B$ at the region of 


\section{$0.4 \sim 1.5 \mu$.}

The extent of denaturation of heat-treated $11 \mathrm{~S}$ globulin $\left(100^{\circ} \mathrm{C}, 5 \mathrm{~min}\right)$ dissolved in the standard buffer which is frequently used in soy proteins, ${ }^{2,3)}$ could be determined by the curve B of Fig. 3 as follows: since this buffer was composed of phosphate buffer at $0.1 \mu$ and $0.4 \mathrm{M} \mathrm{NaCl}$, thermally denatured $11 \mathrm{~S}$ globulin retained portions of the native conformation (or some similar structured regions) in $10 \%$ antigenicity remaining. When $11 \mathrm{~S}$ globulins $(0.5 \%)$ dissolved in $\mathrm{pH} 7.6$ phosphate buffer in the presence of $1.0 \mathrm{M}$ and $2.0 \mathrm{M} \mathrm{NaCl}$ that have been used in the literature data ${ }^{4,5)}$ were heated at $100^{\circ} \mathrm{C}$ for $5 \mathrm{~min}$, the stabilizing effects of $\mathrm{NaCl}$ were determined in values approximately $50 \%$ remaining nearly the same in $2.0 \mathrm{M} \mathrm{NaCl}$ as in $1.0 \mathrm{M} \mathrm{NaCl}$. There was little difference with percent antigenicity between $\mathrm{KCl}$ and $\mathrm{NaCl}$ (Fig. 3) and with or without the

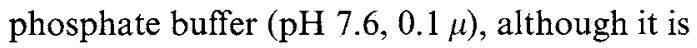
not shown in Fig. 3.

There is little knowledge about relationship between the structural status and the location of the antigenic determinants of $11 \mathrm{~S}$ globulin. Catsimpoolas $^{9,10)}$ demonstrated that the destruction of the quaternary structure of $11 \mathrm{~S}$ globulin by dissociation brings about the complete loss of antigenicity. Attempts at various modifications were made to determine the role of disulfide bonds and the conformational dependence. Figure 4 shows the changes in the antigenic properties of $11 \mathrm{~S}$ globulin treated with various modifications and these disc electrophoretic patterns. No apparent changes were observed after $N$ ethylmaleimide treatment of $11 \mathrm{~S}$ globulin, but reduced and $S$-carboxyamidemethylated $11 \mathrm{~S}$ globulin showed complete loss of antigenicity as the result of dissociation into subunits. Intermediary subunit, IS-3, ${ }^{*}$ gave a halo of very weak precipitate against anti-11S serum though the size of the ring did not change so much. A new model of subunit structure of $11 \mathrm{~S}$ globulin, recently proposed by Kitamura and Shibasaki, ${ }^{14)}$ consisted of three kinds of intermediary subunits (IS-1, $-2,-3$ ) which are composed of a pair of the acidic and the basic subunits through disulfide linkage. The experimental result (Fig. 4) demonstrated that some antigenic determinants were located on the intermediary subunits and the major determinants may be mostly conformationdependent, similarly on many globular proteins as reported by Sela. ${ }^{21}$ In order to gain the conformational antigenic determinants, completely, it will be necessary that the

* IS-3 was obtained from Dr. K. Kitamura.

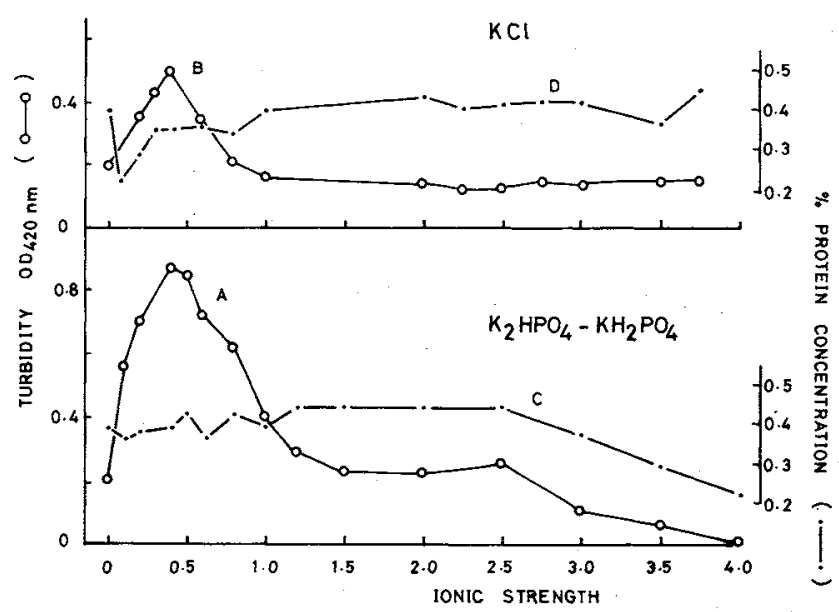

FIG. 5. Turbidity Developed by Heating 11S Globulins at Various Ionic Strengths.

(A) $\mathrm{K}_{2} \mathrm{HPO}_{4}-\mathrm{KH}_{2} \mathrm{PO}_{4}$ buffer and (B) $\mathrm{KCl}$ solvent. The protein concentrations of each unheated sample were indicated at $(\mathrm{C})$ and $(\mathrm{D})$. 
intermediary subunits are assembled into $11 \mathrm{~S}$ dimer or 11S monomer which possesses the quaternary structure.

\section{Turbidity}

Figure 5 illustrated that thermal aggregation was maximal in $0.4 \mu$ both phosphate buffer and $\mathrm{KCl}$ solvent, and $\mathrm{KCl}$ solvent showed a slight turbidity compared with phosphate buffer while the solutions of $11 \mathrm{~S}$ globulin are equal in ionic strength. At these ionic strengths around $0.4 \mu, 11 \mathrm{~S}$ globulins were not precipitated when heated at $100^{\circ} \mathrm{C}$. Aggregation was supressed by increasing the ionic strength above 0.4. At higher ionic strength $(>3.0 \mu)$, the solubility of $11 \mathrm{~S}$ globulin in phosphate buffer differed from that in $\mathrm{KCl}$ solvent: higher concentration of potassium phosphate salted-out ${ }^{7)}$ the $11 \mathrm{~S}$ globulin from solution (Fig. 5C).

It is known that dissociation into subunits is a necessary step prior to thermal aggregation. ${ }^{2 \sim 4)}$ From the data described above, the relationship between denaturation and aggregation was considered as follows: (1) destruction of the quaternary structure (denaturation) was accelerated at low ionic strength near zero; (2) the increase in ionic strength up to 0.4 brought about the acceleration of aggregation of dissociated subunits by the presence of salts; (3) further increase in ionic strength above 0.4 gradually suppressed aggregation of dissociated subunits followed by preventing the destruction of the quaternary structure of $11 \mathrm{~S}$ globulin.

\section{Disc electrophoresis}

Figure 6 shows disc electrophoretic patterns and these densitometric scannings of thermally denatured $11 \mathrm{~S}$ globulins at various ionic strenghts. When $11 \mathrm{~S}$ globulins were heated at low ionic strength (below 0.7 in phosphate buffer and below 0.3 in $\mathrm{KCl}$ solvent), structural-retained $11 \mathrm{~S}$ globulin was not found to be present as seen by disc electrophoresis while many dissociated and/or associated bands appeared. The band $\mathrm{f}(\mathrm{Rm} 0.68)$ referred to the dissociated subunits of $3 \sim 4 \mathrm{~S} .^{2,3,9)}$
Identifications of other bands (a to e, Fig. 6) appeared at low ionic strength region are as follows: these bands may represent dissociated and/or associated products, which migrate at approximately the same positions as the polymer ( $\mathrm{P}, \mathrm{Rm} 0.04$ ), dimer ( $\mathrm{D}, \mathrm{Rm} \mathrm{0.14}$ ), and monomer (M, Rm 0.24$)$ of $11 \mathrm{~S}$ globulin and can be distinguished from the latter by the loss of antigenic activity against anti-11S. The $11 \mathrm{~S}$ dimer band (D) could be distinctly detected above $0.8 \mu$ with phosphate buffer and above $0.6 \mu$ with $\mathrm{KCl}$ solvent. The major structural transition of $11 \mathrm{~S}$ globulin during heating, as shown in Fig. 6 , occurred at these ionic strength regions. When the presence of salt was enough to stabilize the $11 \mathrm{~S}$ molecule, dissociates could not be detected no longer after heating (Fig. 6, $\mu>2.0$ ). The marked correlation was observed between electrophoretic patterns and immunological properties. However, antigenic activity remaining in samples under denaturing conditions was due to undissociated $11 \mathrm{~S}$ molecule which was also shown to be presented by electrophoresis. Therefore it could be qualified that loss of antigenicity is not the production of antigenic polymers of undissociated molecule which impeded diffusion through the gel but is due to the destruction of native conformation followed by the formation of dissociated subunits (Figs. 3, 5 and 6). ${ }^{8)}$

\section{DISCUSSION}

It has been shown that the nature of thermal denaturation of $11 \mathrm{~S}$ globulin was clarified from the estimation of the amount of immunologically unaltered $11 \mathrm{~S}$ globulin remaining in each sample after heating in a wide range of ionic strength. Our experimental results provided that thermal denaturation of $11 \mathrm{~S}$ globulin is a very sensitive one to the ionic strength. Even if the ionic strength of phosphate buffer is equal to that of $\mathrm{KCl}$ solvent (e.g., near $0.4 \sim 1.5 \mu$ ) the obtained percent antigenicity is nonidentical (Fig. 3). Recently, Nakamura et $a .^{22)}$ found that the effect of heating on ovotransferrin varied with ionic strengths 
A

$$
\mathrm{K}_{2} \mathrm{HPO}_{4}-\mathrm{KH}_{2} \mathrm{PO}_{4}
$$
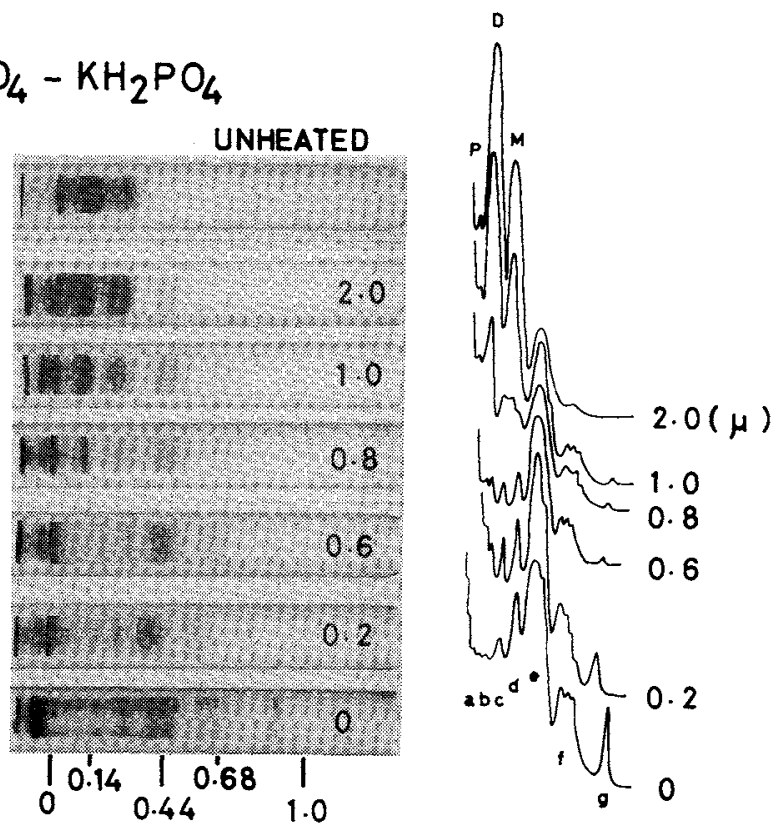

B

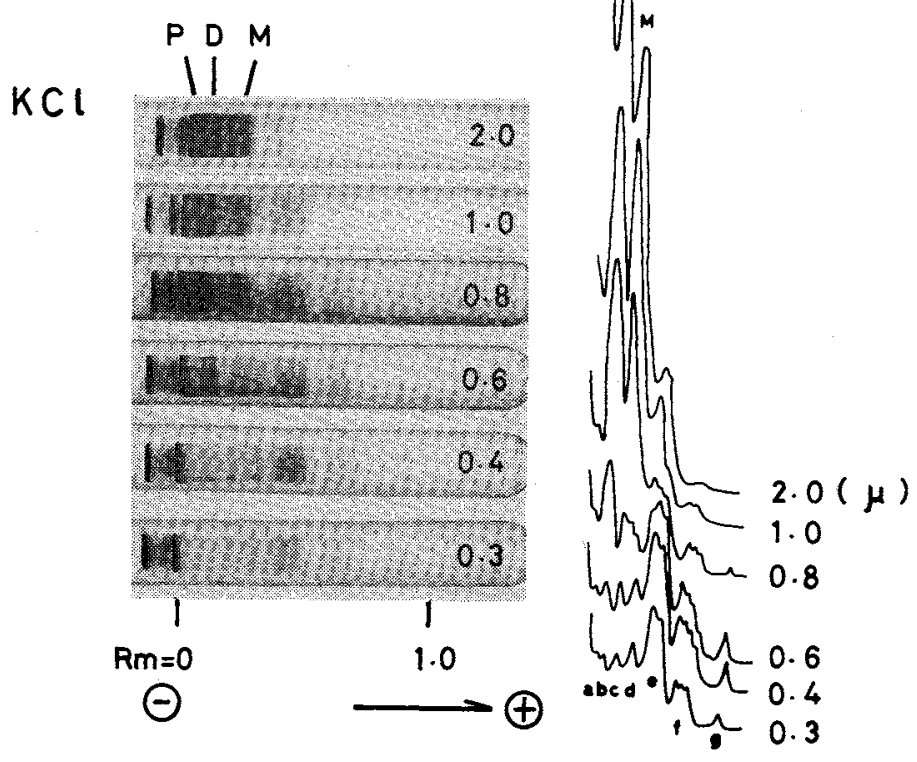

FIG. 6. Disc Electrophoresis Patterns and Densitometric Scannings of $11 \mathrm{~S}$ Globulins Heated for $5 \mathrm{~min}$ at $100^{\circ} \mathrm{C}$ as a Function of Ionic Strength.

A: $\mathrm{K}_{2} \mathrm{HPO}_{4}-\mathrm{KH}_{2} \mathrm{PO}_{4}$ series $(\mu=0 \sim 2.0)$, and unheated control. B: $\mathrm{KCl}$ series $(\mu=0.3 \sim 2.0)$.

added salts in which sodium phosphate was different from other salts $(\mathrm{NaCl}, \mathrm{KCl}$ etc.). However, these results suggest that mechanism of thermal denaturation of soy $11 \mathrm{~S}$ globulin may differ from one another in the type of salts, potassium phosphate and $\mathrm{KCl}$, whether salts possess a buffer capacity or not.

It is separable the nature of stabilizing effect 
of salts on the thermal denaturation $\left(100^{\circ} \mathrm{C}\right.$, $5 \mathrm{~min}$ ) of $11 \mathrm{~S}$ globulin into three regions: (1) At low ionic strength below 0.7 , potassium phosphate produced no stabilizing effect. It was also shown by electrophoresis that thermally denatured $11 \mathrm{~S}$ globulin possessed no undissociated molecules and completely dissociated into subunits and/or associated. (2) The rise in stabilizing effect (in terms of percent antigenicity) up to $50 \%$ near $1.0 \sim 1.5 \mu$ represented a second transition to a different denatured state which may retain more ordered structure. (3) Rapid increase in the resistance to the thermal denaturation near $2.5 \sim 3.0 \mu$ represented a third transition to a different structural status in which almost regions may retain its native comformation or some native-like structure. This unexpected resistance to heat denaturation of 11S. globulin at the highly concentrated salt solutions may originate from the fact that potassium phosphate stabilizes the native conformation because of this salting-out effect as reported by Hippel and Wong. ${ }^{7)}$ Thus, the stabilizing effect of salts on thermal denaturation of $11 \mathrm{~S}$ globulin is not simple but complicated. These results may be due to the $11 \mathrm{~S}$ molecule which contains several areas of different structural compactness. ${ }^{23)}$ Since only immunodiffusion technique was used in this report, it will be necessary to utilize several other methods such as quantitative precipitin and other analytical methods for clarifying the structural status.

On the other hand, Wolf and Tamura ${ }^{3)}$ reported that when $11 \mathrm{~S}$ globulin is heated, cleavage of disulfide bonds occurs and native molecule is disrupted into subunits. We have shown that if disulfide bonds are disrupted by heating, the halo of precipitation is no longer formed (Fig. 4). The antigenic activity nevertheless remained in the heat-denatured $11 \mathrm{~S}$ globulin especially at higher ionic strength regions. All of the above data, at these conditions, provided evidence for the existence of the $11 \mathrm{~S}$ molecule with disulfide bond intact at least in the region of the antigenic sites after heating $\left(100^{\circ} \mathrm{C}, 5 \mathrm{~min}\right)$.

Catsimpoolas et $a .^{10)}$ reported that $11 \mathrm{~S}$ globulin in $0.85 \% \mathrm{NaCl}$ rapidly loses its antigenicity by heating at $70 \sim 90^{\circ} \mathrm{C}$. In this case, our thermal denaturation data of Fig. 3 suggest that the $\mathrm{NaCl}$ concentration is not enough to stabilize the $11 \mathrm{~S}$ molecule against heating because of its low ionic strength about 0.15 . It makes possible to prepare the thermally denatured $11 \mathrm{~S}$ globulins which have desired-residual amounts of structured regions by means of the selection of an adequate ionic strength. It is of interest that gels formed from completely denatured- or $50 \%$ denatured-11S globulin (see Fig. 3) can be expected to differ in their functional properties; this is now in progress.

Although an immunological method was used for quantitating of $\alpha$-lactalbumin and $\beta$ lactoglobulin in dairy products, ${ }^{24)}$ there are few reports on the utilization of this technique for soy products. The data of Fig. 3 provide strong possibility of application of this immunological method for the measurement of soy protein (11S) remained in heat-treated soy products if these contain only an adequate amount of $\mathrm{NaCl}$ at least $2 \%$.

Acknowledgment. The authors are grateful to Dr. K. Oba for helpful advice on immunology.

\section{REFERENCES}

1) C. Tanford, Adv. Protein Chem., 23, 121 (1968).

2) K. Hashizume and T. Watanabe, Agric. Biol. Chem., 39, 1339 (1975).

3) W. J. Wolf and T. Tamura, Cereal Chem., 46, 331 (1969).

4) N. Catsimpoolas, S. K. Funk and Meyer, Cereal Chem., 47, 331 (1970).

5) A. M. Hermansson, J. Text. Studies, 9, 33 (1978).

6) K. C. Aune, A. Salahunddin, M. H. Zarlengo and C. Tanford, J. Biol. Chem., 242, 4486 (1967).

7) P. H. von Hippel and K. Y. Wong, Science, 145, 577 (1964).

8) K. Wada, J. Biochem., 86, (1979).

9) N. Catsimpoolas, T. G. Campbell and E. W. Meyer, Arch. Biochem. Biophys., 131, 577 (1969).

10) N. Catsimpoolas, J. Kenny and E. W. Meyer, Biochim. Biophys. Acta, 229, 451 (1971).

11) J. F. Gerstein, H. Van Vunakis and L. Levine, Biochemistry, 2, 964 (1963).

12) L. G. Chavez and H. A. Scheraga, Biochemistry, 16, 
1849 (1977).

13) B. H. Thanh and K. Shibasaki, J. Agric. Food Chem., 24, 1117 (1976).

14) K. Kitamura and K. Shibasaki, Agric. Biol. Chem., 40, 1837 (1976).

15) W. J. Wolf and D. R. Briggs, Arch. Biochem. Biophys., 85, 186 (1959).

16) I. Koshiyama, Int. J. Peptide Protein Res., 4, 167 (1972).

17) I. Koshiyama and D. Fukushima, Phytochemistry, 15, 157 (1976).

18) N. Catsimpoolas and E. W. Meyer, Arch. Biochem.
Biophys., 125, 742 (1968).

19) G. Mancini, A. O. Carbonara and J. F. Heremans, Immunochemistry, 2, 235 (1965).

20) A. H. Reisner, P. Nemes and C. Bucholtz, Anal. Biochem., 64, 509 (1975).

21) M. Sela, Science, 166, 1365 (1969).

22) R. Nakamura, O. Umemura and H. Takemoto, Agric. Biol. Chem., 43, 325 (1979).

23) M. Draper and N. Catsimpoolas, Cereal Chem., 55, 16 (1978).

24) T. M. Dougherty, J. Food Sci., 42, 1611 (1977). 